\title{
Ghost protein damage by peroxynitrite and its protection by melatonin
}

\section{P. Di Mascio ${ }^{1}$, \\ B. Dewez $z^{1}$ and \\ C.R.S. Garcia²}

1Departamento de Bioquímica, Instituto de Química, and ${ }^{2}$ Departamento de Fisiologia, Instituto de Biociências, Universidade de São Paulo, São Paulo, SP, Brasil

\section{Correspondence \\ P. Di Mascio \\ Departamento de Bioquímica Instituto de Química, USP \\ Caixa Postal 26077 \\ 05599-970 São Paulo, SP \\ Brasil \\ Fax: +55-11-815-5579 \\ E-mail: pdmascio@ iq.usp.br \\ Departmental website: http:// \\ www.iq.usp.br/bioquimica/index.html \\ Research supported by FAPESP, CNPq and PRONEX/FINEP. B. Dewez was the recipient of a FAPESP fellowship.}

Received February 24, 1999 Accepted O ctober 25, 1999

\section{Abstract}

We have studied the effect of peroxynitrite $\left(\mathrm{ONOO}^{-}\right)$on the membrane cytoskeleton of red blood cells and its protection by melatonin. Analysis of the protein fraction of the preparation by SDS-PAGE revealed a dose-dependent $\left(0-600 \mu \mathrm{M} \mathrm{ONOO}^{-}\right)$disappearance at $\mathrm{pH}$ 7.4 of the main proteins: spectrin, band 3 , and actin, with the concomitant formation of high-molecular weight aggregates resistant to reduction by $ß$-mercaptoethanol $(2 \%)$ at room temperature for $20 \mathrm{~min}$. These aggregates were not solubilized by $8 \mathrm{M}$ urea. Incubation of the membrane cytoskeleton with $\mathrm{ONOO}^{-}$was characterized by a marked depletion of free sulfhydryl groups $\left(50 \%\right.$ at $\left.250 \mu \mathrm{M} \mathrm{ONOO}^{-}\right)$. However, a lack of effect of $\beta$-mercaptoethanol suggests that, under our conditions, aggregate formation is not mediated only by sulfhydryl oxidation. The lack of a protective effect of the metal chelator diethylenetriaminepentaacetic acid confirmed that $\mathrm{ONOO}^{-}$-induced oxidative damage does not occur only by a transition metal-dependent mechanism. However, we demonstrated a strong protection against cytoskeletal alterations by desferrioxamine, which has been described as a direct scavenger of the protonated form of peroxynitrite. Desferrioxamine $(0.5 \mathrm{mM})$ also inhibited the loss of tryptophan fluorescence observed when the ghosts were treated with $\mathrm{ONOO}^{-}$. Glutathione, cysteine, and Trolox ${ }^{\circledR}(1 \mathrm{mM})$, but not mannitol $(100 \mathrm{mM})$, were able to protect the proteins against the effect of $\mathrm{ONOO}^{-}$in a dose-dependent manner. Melatonin (0-1 mM) was especially efficient in reducing the loss of spectrin proteins when treated with $\mathrm{ONOO}^{-}(90 \%$ at 500 $\mu \mathrm{M}$ melatonin). Our findings show that the cytoskeleton, and in particular spectrin, is a sensitive target for $\mathrm{ONOO}^{-}$. Specific antioxidants can protect against such alterations, which could seriously impair cell dynamics and generate morphological changes.

\section{Key words}

- Peroxynitrite

- Melatonin

- Spectrin

- Protein

- Ghost

- Thiols

\section{Introduction}

Peroxynitrite anion $\left(\mathrm{ONOO}^{-}\right)$, a highly reactive and biologically important species, is produced under physiological conditions and in vivo by the reaction of superoxide anion radical $\left(\mathrm{O}_{2}{ }^{\bullet-}\right)$ with nitric oxide $\left({ }^{\bullet} \mathrm{NO}\right)$, $\left({ }^{\circ} \mathrm{NO}+\mathrm{O}_{2}{ }^{\cdot-} \rightarrow \mathrm{ONOO}^{-}\right)$(1). Nitric oxide, identified as endothelium-derived relaxing factor, is formed during the conversion of Larginine to L-citrulline by an NO-synthase. Endothelial cells, macrophages, neutrophils and neuronal cells have been shown to produce $\cdot \mathrm{NO}(2,3)$.

At physiological $\mathrm{pH}, \mathrm{ONOO}^{-}$can be protonated and decomposed to an intermediate with reactivity similar to that of hydroxyl radical and nitrogen dioxide (1,4-6). Peroxy- 
nitrite can also react directly with sulfhydryl groups (7). The lifetime of this anion is sufficient for diffusion through the membrane and interaction with hydrogen peroxide (8) and cellular constituents (9). Peroxynitrite oxidizes low molecular weight sulfhydryls to disulfides that can be partially recovered by the glutathione-glutathione reductase system but leads to higher sulfur oxidation states of protein sulfhydryls (7). This damage also occurs in the absence of transition metals $(1,6,9)$. The peroxynitrite anion reacts rapidly with carbon dioxide at a rate constant of $5.8 \times 10^{4} \mathrm{M} / \mathrm{s}$ at $37^{\circ} \mathrm{C}$, producing an adduct whose structure is proposed to be nitrosoperoxocarboxylate $\left(\mathrm{ONOOCO}_{2}^{-}\right)$and may modulate various biological peroxynitrite-mediated processes (10-12). Peroxynitrites are able to react with lipids, DNA, proteins and small antioxidant molecules such as glutathione $(13,14)$. These rapid and specific reactions are likely to inactivate important cellular targets. It has been shown that $\mathrm{ONOO}^{-}$promotes lipoperoxidation, protein nitration and a decrease of intracellular reduced glutathione in human erythrocyte (15).

Red blood cell (RBC) shape and deformability are regulated by a submembrane cytoskeleton whose major proteins responsible for regulating the membrane topography are: spectrin, actin, ankyrin, band 4.1, band 4.9, and tropomyosin. These proteins are arranged in a network connected to integral membrane proteins along the bilayer membrane through associations between ankyrin and band 3 and between band 4.1 and glycophorin (16). Structural alterations in these membrane proteins can lead to a loss of deformability, which is essential for RBC passage into small blood vessels of specific organs and tissues.

Red blood cell membrane ghosts offer a good model for studying protein damage induced by $\mathrm{ONOO}^{-}$because their protein composition is well known and they lack organelles, which makes them a simple and suitable biological system.

\section{Material and Methods}

\section{Chemicals}

Diethylenetriaminepentaacetic acid (DTPA), 5,5'-dithiobis-(2-nitrobenzoic acid) (DTNB), reduced glutathione (GSH), mannitol, manganese dioxide, hydrogen peroxide, sodium nitrite, acrylamide and pre-stained molecular weight markers were obtained from Sigma Chemical Co. (St. Louis, MO, USA). All other solvents and chemicals used were of analytical grade and were purchased from Merck (Darmstadt, Germany). Water was purified on a Milli-Q system (Millipore, Bedford, MA, USA).

\section{Synthesis of peroxynitrite}

Peroxynitrite was synthesized in a quenched flow reactor as described by Beckman et al. (1). Excess $\mathrm{H}_{2} \mathrm{O}_{2}$ was removed by passage over $\mathrm{MnO}_{2}$. The solution was then filtered twice and frozen at $-20^{\circ} \mathrm{C}$ for two days. Peroxynitrite forms a dark yellow top layer due to freeze fractionation, which was removed and stored at $-80^{\circ} \mathrm{C}$ for further experiments (17). This solution contained $200-400 \mathrm{mM} \mathrm{ONOO}^{-}$as determined by absorbance at $302 \mathrm{~nm}\left(\varepsilon_{302}=1,670 \mathrm{M} /\right.$ $\mathrm{cm})$.

\section{Preparation of red blood cell ghosts and SDS-PAGE}

Mouse blood was freshly collected into ACD ( $75 \mathrm{mM}$ trisodium citrate, $42 \mathrm{mM}$ citric acid and $139 \mathrm{mM}$ glucose). After washing with phosphate-buffered saline (PBS), the leukocytes and platelets were removed by cellulose filtration (18). The eluate from the column was washed three times with PBS. Erythrocyte ghosts were prepared according to the method described by Tyler et al. (19). RBC lysis was performed by the 
addition of 20 volumes of lysis buffer $(5 \mathrm{mM}$ phosphate, $\mathrm{pH}$ 8.0, and $0.1 \mathrm{mM}$ ethylenediaminetetraacetate (EDTA)). After lysis, the ghosts were sedimented at $19,000 \mathrm{~g}$ for 10 min and the pellet was washed in lysis buffer until hemoglobin was eliminated. The final pellet was resuspended in PBS.

\section{Exposure of the membrane cytoskeleton to peroxynitrite}

Peroxynitrite concentration was measured by the increase in absorbance at $302 \mathrm{~nm}$ in $1.2 \mathrm{M} \mathrm{NaOH}$. The membrane cytoskeleton $(\sim 200 \mu \mathrm{g}$ proteins $/ \mathrm{ml})$ was incubated with synthesized $\mathrm{ONOO}^{-}$in $50 \mathrm{mM}$ potassium phosphate buffer, $\mathrm{pH}$ 7.4. The reaction was performed by placing a small aliquot of ONOO$^{-}(2-6 \mu \mathrm{l})$ on the side of a tube containing the membrane cytoskeleton solution immediately followed by vigorous vortexing. As a control for the potential effects of nitrite, nitrate and $\mathrm{H}_{2} \mathrm{O}_{2}$, traces of which can be present in synthesized peroxynitrite, $\mathrm{ONOO}^{-}$ was allowed to decompose for $5 \mathrm{~min}$ in potassium phosphate buffer, $\mathrm{pH} 7.4$, before the addition of the cytoskeleton. To insure that $\mathrm{ONOO}^{-}$was decomposed, we measured the absorbance of $\mathrm{ONOO}^{-}$in $50 \mathrm{mM}$ potassium phosphate buffer, $\mathrm{pH} 7.4$, at $302 \mathrm{~nm}$. After $5 \mathrm{~min}$, the absorbance at $302 \mathrm{~nm}$ of the decomposed $\mathrm{ONOO}^{-}$was the same as that of the buffer alone. The membrane cytoskeleton was incubated in the presence of peroxynitrite for $20 \mathrm{~min}$ at room temperature. After incubation, erythrocyte ghosts were sedimented, the degradation products contained in the buffer were eliminated, and the final pellet was dissolved in $8 \mathrm{M}$ urea/1\% SDS for protein and thiol measurement or in electrophoresis sample buffer containing $10 \%$ SDS and $2 \%$ mercaptoethanol.

\section{SDS-polyacrylamide gel electrophoresis}

The samples were solubilized in electrophoresis sample buffer and submitted to SDS-
PAGE in a $3.5-12 \%$ polyacrylamide gradient gel (20). The gels were stained with Coomassie brilliant blue R-250 and the protein bands were scanned with a Schimadzu (C-9000, Japan) densitometer.

\section{Protein measurement}

Membrane cytoskeleton protein was measured by the method of Lowry et al. (21) and/or according to the method of Bradford (22) (Biorad assay; Biorad Laboratories, Hercules, CA, USA).

\section{Protein sulfhydryl group determination}

Sulfhydryl groups were measured using the DTNB procedure described by Di Monte et al. (23).

\section{Fluorescence measurement}

Oxidation of tryptophan (excitation $\lambda=$ $295 \mathrm{~nm}$ and emission $\lambda=310-450 \mathrm{~nm}$ ) or melatonin (excitation $\lambda=272 \mathrm{~nm}$ and emission $\lambda=290-450 \mathrm{~nm}$ ) was monitored by changes in fluorescence. Fluorescence spectra were recorded on a Spex 1681 spectrometer (Spex, Edison, NJ, USA) coupled to a 386DX personal computer.

\section{Results and Discussion}

Exposure of RBC ghost membrane cytoskeletons to $\mathrm{ONOO}^{-}$for $20 \mathrm{~min}$ induced modifications in the polypeptide pattern observed by SDS-PAGE (Figure 1A and B). In the peroxynitrite-exposed cytoskeleton, two major changes in the polypeptide composition of the ghost proteins were evident, namely the appearance of a large-molecular weight aggregate $(>200 \mathrm{kDa})$ and a dosedependent decrease in the amount of polypeptides migrating in the gel, with a major effect on spectrin bands. Two bands between spectrin and band 3 with a molecular weight $<198 \mathrm{kDa}$ were observed, which dis- 
Figure 1 - SDS-polyacrylamide gel electrophoresis of red blood cell ghosts $(A)$ and percentage of band 3 (B) after treatment with different concentrations of peroxynitrite (lanes $0,1,2,3,4,5,6$ are $0,74,148,296,444,592$, $740 \mu \mathrm{M}$ peroxynitrite, respectively), for $20 \mathrm{~min}$ at room temperature. The first band on the gel (MW) contains a mixture of proteins of different molecular masses $(\mathrm{kDa})$ as reference. the $\alpha$ spectrin, $B$ spectrin and

appeared at higher $\mathrm{ONOO}^{-}$concentrations. The main effect was a dose-dependent decrease in the amount of $\alpha$ spectrin, $\beta$ spectrin and band 3 (Figure 1B). At low $\mathrm{ONOO}^{-}$ concentrations, other protein bands remain intact, possibly indicating a certain specificity of $\mathrm{ONOO}^{-}$for the ghost proteins. Exposure to $740 \mu \mathrm{M}$ peroxynitrite induced a drastic effect, with the disappearance of almost

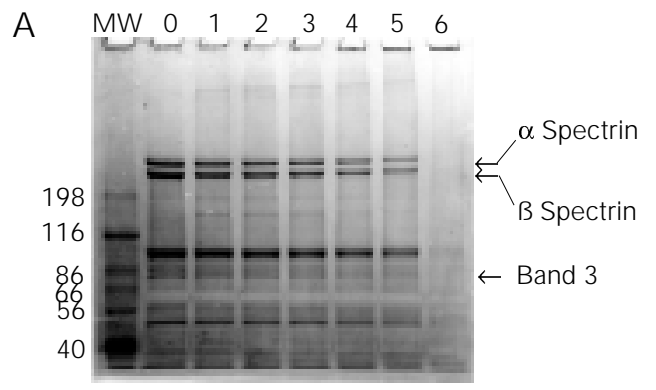

B

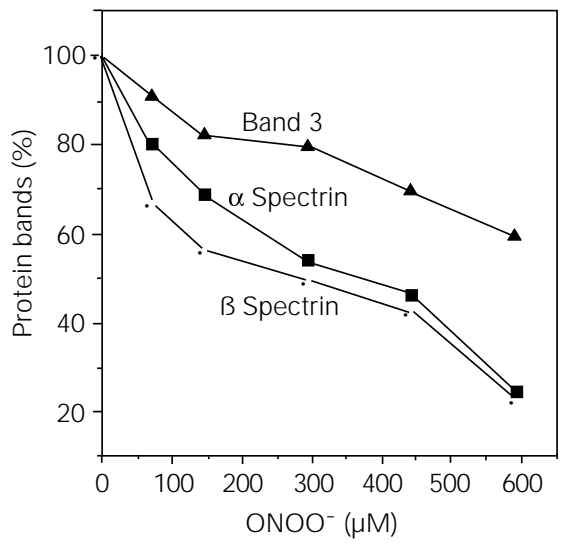

Figure 2 - Measurement of sulfhydryl groups (open circles) and tryptophan fluorescence intensity (filled circles) after reaction with different concentrations of peroxynitrite for $20 \mathrm{~min}$ at room temperature.

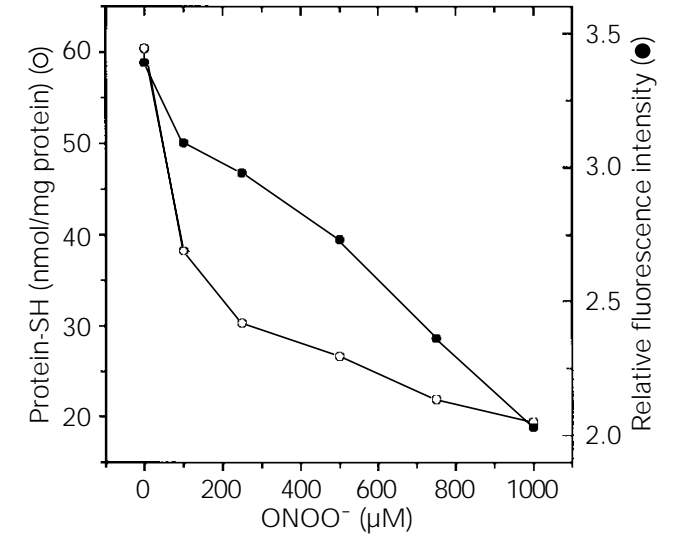

all polypeptides (Figure 1A, Band 6). The disappearance of these proteins is consistent with an increase in the size of the pellet obtained prior to electrophoresis (data not shown). Loss of polypeptides through a hydrolytic mechanism of reactive oxygen species as described by Davies and Delsignore (24), and particularly of $\mathrm{ONOO}^{-}$(25) can be excluded by measuring the total amount of ghost proteins and comparing this with the solubilized pellet content. No difference in the quantity of proteins was detected in the control or treated samples. Mallozzi et al. (26) investigated the effects of $\mathrm{ONOO}^{-}$on human erythrocytes and obtained two different responses. At low concentration $(<100$ $\mu \mathrm{M}) \mathrm{ONOO}^{-}$stimulated a metabolic response of phosphorylation activity and at high concentration $(>200 \mu \mathrm{M})$ it caused cross-linking of membrane proteins, nitration of tyrosines and massive methemoglobin production.

Among the major targets of $\mathrm{ONOO}^{-}$are $\mathrm{R}-\mathrm{SH}$ groups (7). Figure 2 shows a dosedependent decrease of R-SH groups (50\% at $250 \mu \mathrm{M} \mathrm{ONOO}^{-}$) in ghost proteins when treated with $\mathrm{ONOO}^{-}$. The extent of lesion to the spectrin bands was slightly different when $\mathrm{ONOO}^{-}$treatment was performed in the presence of urea or under reducing conditions using B-mercaptoethanol. This result suggests that crosslinking reactions other than disulfide formation contribute to aggregate formation. Thiol groups and tryptophan have been shown to be susceptible to $\mathrm{ONOO}^{-}$ attack (7). Similarly, tryptophan residues from the ghost proteins are affected by $\mathrm{ONOO}^{-}$. The loss of R-SH shown in Figure 2 is paralleled by a decrease in fluorescence intensity at $330 \mathrm{~nm}$ after excitation at $295 \mathrm{~nm}$ after treatment with different $\mathrm{ONOO}^{-}$concentrations. Analysis of the fluorescence spectra after treatment in the presence of 0.5 $\mathrm{mM}$ desferrioxamine (Figure 3, b) or 0.5 mM DTPA (Figure 3, c) showed that desferrioxamine has a protecting effect compared to $0.5 \mathrm{mM} \mathrm{ONOO}^{-}$alone. The loss of tryp- 
tophan fluorescence induced by $\mathrm{ONOO}^{-}$is due to the formation of nitrotryptophan, visible with the presence of a yellow color (27). These experiments were confirmed also using tryptophan (data not shown).

Desferrioxamine $(0.5 \mathrm{mM})$ is able to protect against the disappearance of the spectrin bands (Figure 4). This confirms the results obtained for tryptophan fluorescence with $0.5 \mathrm{mM}$ desferrioxamine (Figure 3), which can be explained by the scavenging effect of desferrioxamine on trans-peroxynitrite (28). Diethylenetriaminepentaacetic acid $(0.5 \mathrm{mM})$ was a weak inhibitor of the $\mathrm{ONOO}^{-}$reaction (Figure 4), chelating transition metals involved in the process $(1,10)$, but otherwise having no direct effect. Mannitol at $100 \mathrm{mM}$ was used in the presence of $\mathrm{ONOO}^{-}$to evaluate the contribution of hydroxyl radicals to ghost damage. Only a $10 \%$ protective effect on the disappearance of spectrin bands could be observed (data not shown). This result shows that hydroxyl radicals are not the main reactive species in this system $(11,12,28,29)$. However, nitrogen dioxide formed by the decomposition of $\mathrm{ONOO}^{-}$ may also be involved in this damage (30). Glutathione and cysteine ( $1 \mathrm{mM})$ were highly effective in protecting spectrin against $\mathrm{ONOO}^{-}$-mediated damage (Figure 5). It is known that glutathione is very important for the maintenance of erythrocyte integrity. Similarly, plasmid DNA damage caused by $\mathrm{ONOO}^{-}$was inhibited by these compounds in vitro $(12,14)$.

Melatonin has been demonstrated to be a very efficient scavenger of reactive oxygen species, especially hydroxyl radicals, in biological systems (31). Pieri et al. (32) demonstrated that melatonin is a better scavenger of hydroxyl radicals than $\alpha$-tocopherol. In contrast, Barsacchi et al. (33) showed that vitamin E consumption by red blood cells is enhanced by melatonin under oxidative stress induced by cumene hydroperoxide or $\mathrm{H}_{2} \mathrm{O}_{2}$. In other experiments, melatonin reduced the levels of DNA adduct induced by the car-

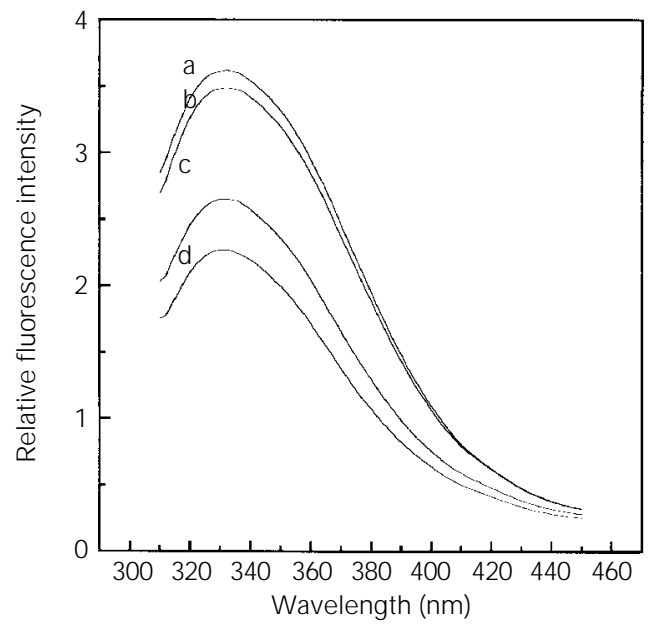

Figure 3 - Fluorescence spectra of red blood cell ghosts. Proteins were treated with a) no ONOO-, b) $0.5 \mathrm{mM}^{\mathrm{ONOO}}$ and $0.5 \mathrm{mM}^{-}$ desferrioxamine, c) $0.5 \mathrm{mM}$ ONOO- and 0.5 mM DTPA, and d) $0.5 \mathrm{mM} \mathrm{ONOO}^{-}$, for $20 \mathrm{~min}$ at room temperature.

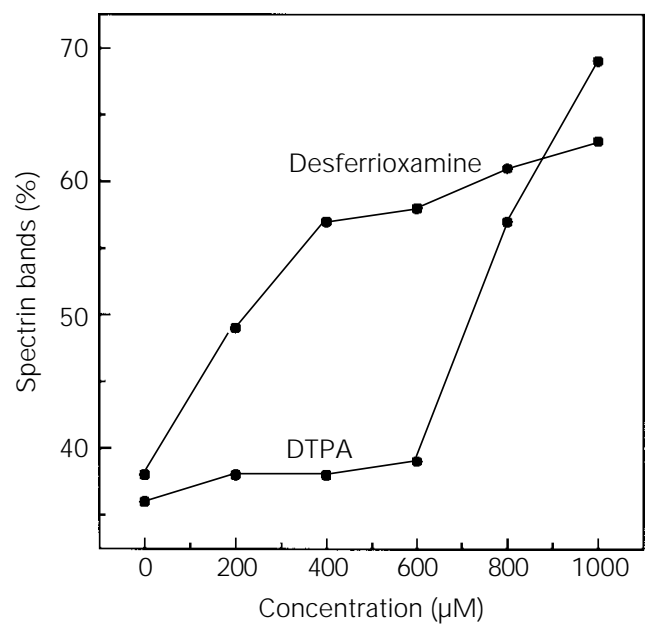

Figure 4 - Protection of spectrin proteins by desferrioxamine and diethylenetriaminepentaacetic acid (DTPA). Spectrin proteins were measured after treatment with $500 \mu \mathrm{M}$ peroxynitrite in the presence of different concentrations of desferrioxamine and DTPA at room temperature for 20 min.

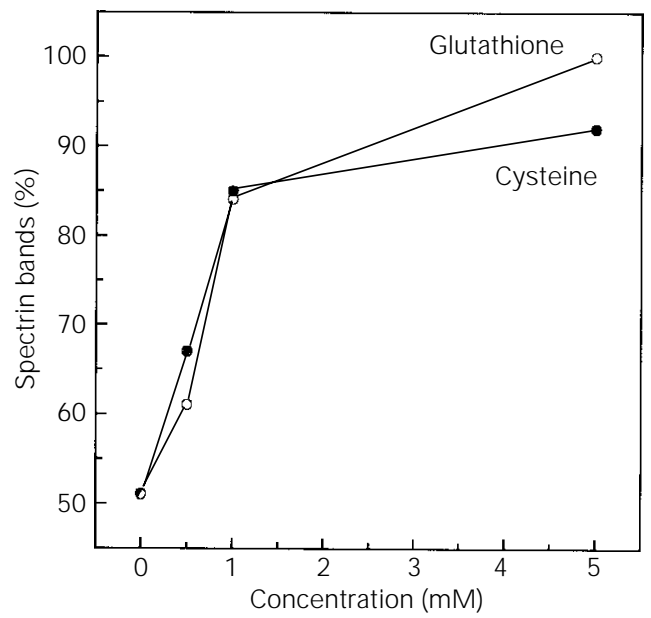

Figure 5 - Protective effect of different concentrations of glutathione (open circles) and cysteine (filled circles) on the protein damage induced by $0.5 \mathrm{mM}$ ONOO- at room temperature for 20 min. 
Figure 6 - Red blood cell ghosts cytoskeleton protection by melatonin in the presence of peroxynitrite. Inset: Fluorescence spectra of $10 \mu \mathrm{M}$ melatonin when treated with ONOO-: a) no $\mathrm{ONOO}^{-}$, b) $0.5 \mathrm{mM}^{\mathrm{ONOO}}{ }^{-}$, c) 1 $\mathrm{mM}^{-} \mathrm{ONOO}^{-}$and d) $2.5 \mathrm{mM}$ $\mathrm{ONOO}^{-}$, for $20 \mathrm{~min}$ at room temperature.

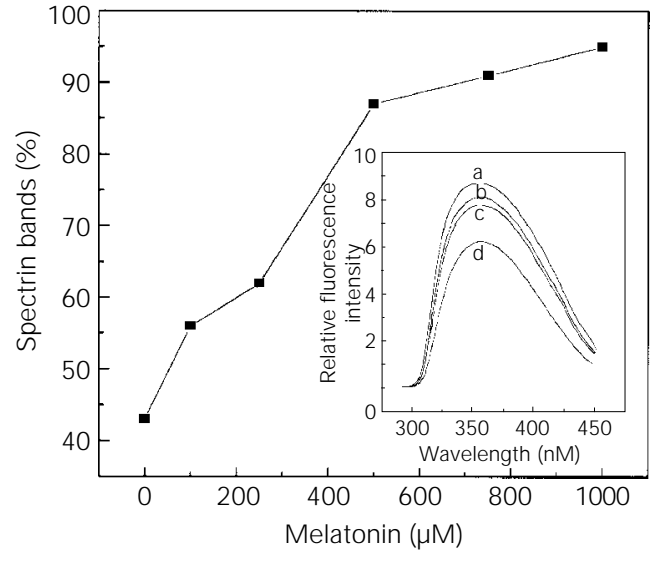

cinogen safrol $(34,35)$. The use of this hormone in our model revealed that this is a very good protector of erythrocyte proteins against $\mathrm{ONOO}^{-}$-induced damage. In fact, with 500 $\mu \mathrm{M}$ melatonin, the protective effect was almost $90 \%$ (Figure 6). At lower concentrations, melatonin was more efficient than glutathione or cysteine. At physiological concentrations (50-1000 pg/ml plasma) (36), melatonin was also able to control the quantity of $\cdot \mathrm{NO}$ generated via the NO-synthase reaction (37). Since melatonin has an indole moiety, like tryptophan, we also measured the fluorescence spectra of melatonin in the presence of different $\mathrm{ONOO}^{-}$concentrations (Figure 6, inset). As in the tryptophan experiments, a loss of fluorescence intensity was observed, showing that melatonin scavenges peroxynitrite.

$\operatorname{Trolox}^{\circledR}(1 \mathrm{mM})$, the more water-soluble $\alpha$-tocopherol analog, was also able to protect against protein damage, in a manner similar to melatonin (data not shown). Peroxynitrite-induced erythrocyte hemolysis was also demonstrated to be partially suppressed by Trolox ${ }^{\circledR}$ and other antioxidants (38). Interestingly, another class of antioxidants, the pyrrolopyrimidines, prevented nitrotyrosine formation in peroxynitrite-treated red blood cell membranes, but had little effect on membrane cross-linking (39).

The present data show that the erythrocyte cytoskeleton is a sensitive target for $\mathrm{ONOO}^{-}$. Spectrin is the main target of $\mathrm{ONOO}^{-}$, and can be protected by melatonin and thiol antioxidants. Such alterations of spectrin could seriously impair cell dynamics and generate morphological changes, and can be prevented by specific antioxidants.

\section{Acknowledgments}

We thank Chuck Saker Farah and Brian Bandy, Departamento de Bioquímica, Instituto de Química, Universidade de São Paulo, for reading the manuscript.

\section{References}

1. Beckman J S, Beckman TW, Chen J, Marshall PA \& Freeman BA (1990). Apparent hydroxyl radical production by peroxynitrite: implication for endothelial injury from nitric oxide and superoxide. Proceedings of the National Academy of Sciences, USA, 87: 1620-1624.

2. Ischiropoulos $H$, Zhu $L \&$ Beckman JS (1992). Peroxynitrite formation from macrophage-derived nitric oxide. Archives of Biochemistry and Biophysics, 298: 446451.

3. Kooy NW \& Royall JA (1994). Agonistinduced peroxynitrite production from endothelial cells. Archives of Biochemistry and Biophysics, 310: 352-359.

4. Pryor WA, J in X \& Squadrito GL (1994).
One- and two-electron oxidations of methionine by peroxynitrite. Proceedings of the National Academy of Sciences, USA, 91: 11173-11177.

5. van $\operatorname{der}$ Vliet $A$, O'Neill CA, Halliwell B, Cross CE \& Kaur H (1994). Aromatic hydroxylation and nitration of phenylalanine and tyrosine by peroxynitrite. Evidence for hydroxyl radical production from peroxynitrite. FEBS Letters, 339: 89-92.

6. Augusto O, Gatti RM \& Radi R (1994). Spin-trapping studies of peroxynitrite decomposition and of 3-morpholinosydnonimine N-ethylcarbamide autoxidation: direct evidence for metal-independent formation of free radical intermediates. Archives of Biochemistry and Biophysics,
310: 118-125.

7. Radi R, Beckman J S, Bush KM \& Freeman BA (1991). Peroxynitrite oxidation of sulfhydryls: the cytotoxic potential of superoxide and nitric oxide. J ournal of Biological Chemistry, 266: 4244-4250.

8. Di Mascio P, Bechara EJ H, Medeiros MHG, Briviba K \& Sies H (1994). Singlet molecular oxygen production in the reaction of peroxynitrite with hydrogen peroxide. FEBS Letters, 355: 287-289.

9. Beckman J S, Chen J, Ischiropoulos $\mathrm{H} \&$ Crow JP (1994). Oxidative chemistry of peroxynitrite. Methods in Enzymology, 233: 229-240.

10. Lymar SV \& Hurst J K (1996). Carbon dioxide: physiological catalyst for peroxyni- 
trite-mediated cellular damage or cellular protectant? Chemical Research in Toxicology, 9: 845-850.

11. Sharov VS, Driomina ES, Briviba K \& Sies $H$ (1998). Sensitization of peroxynitrite chemiluminescence by triplet carbonyl sensitizer coumarin-525. Effect of $\mathrm{CO}_{2}$. Photochemistry and Photobiology, 68: 797-801.

12. Bonini MG, Radi R, Ferrer-Sueta G, Ferreira AM, Da C \& Augusto O (1999). Direct EPR detection of the carbonate radical anion produced from peroxynitrite and carbon dioxide. J ournal of Biological Chemistry, 274: 10802-10806.

13. Salgo MG, Bermudez $E$, Squadrito $G L \&$ Pryor WA (1995). Peroxynitrite causes DNA damage and oxidation of thiols in rat thymocytes. Archives of Biochemistry and Biophysics, 322: 500-505.

14. Douki T, Cadet J \& Ames BN (1996). An adduct between peroxynitrite and 2'-deoxyguanosine: 4,5-dihydro-5-hydroxy-4(nitrosooxy)-2'-deoxyguanosine. Chemical Research in Toxicology, 9: 3-7.

15. Soszynski M \& Bartosz G (1996). Effect of peroxynitrite on enythrocytes. Archives of Biochemistry and Biophysics, 1291: 107114.

16. Bennet V (1985). The membrane skeleton of human erythrocytes and its implication for more complex cells. Annual Review of Biochemistry, 54: 273-304.

17. Di Mascio P, Briviba K, Bechara EJ H, Medeiros MHG \& Sies H (1996). The reaction of peroxynitrite and hydrogen peroxide produces singlet molecular oxygen $\left({ }^{1} \Delta_{\mathrm{g}}\right)$. Methods in Enzymology, 269: 395400.

18. Homewood CA \& Neame KD (1976). A comparison of methods used for removal of white cells from malaria infected blood. Annals of Tropical and Medical Parasitology, 70: 249-251.

19. Tyler TM, Hargraves WR \& Branton D (1980). Associations of erythrocyte membrane protein. Proceedings of the National Academy of Sciences, USA, 70: 51925196.

20. Laemmli UK (1970). Cleavage of struc- tural proteins during the assembly of the head of bacteriophage T4. Nature, 227: 680-685.

21. Lowry O, Rosebrough NJ, Farr AL \& Randall RJ (1951). Protein measurement with the Folin phenol reagent. Biological Chemistry, 183: 265-275.

22. Bradford MM (1976). A rapid and sensitive method for the quantification of microgram quantities of protein utilizing the principle of protein dye binding. Analytical Biochemistry, 7: 248-254.

23. Di Monte D, Ross D, Bellomo G, Eklöw L $\&$ Orrenius $S$ (1984). Alterations in intracellular thiol homeostasis during the metabolism of menadione by isolated rat hepatocytes. Archives of Biochemistry and Biophysics, 235: 334-342.

24. Davies RJ \& Delsignore ME (1987). Protein damage and degradation by oxygen radicals. J ournal of Biological Chemistry, 262: 9908-9913.

25. Ischiropoulos H \& Al-Mehdi AB (1995). Peroxynitrite-mediated oxidative protein modifications. FEBS Letters, 364: 279282.

26. Mallozzi C, Di Stasi AM \& Minetti M (1997). Peroxynitrite modulates tyrosinedependent signal transduction pathway of human erythrocyte band 3. FASEB J ournal, 11: 1281-1290.

27. Alvarez $B$, Rubbo $H$, Kirk $M$, Barnes $S$, Freeman BA \& Radi R (1996). Peroxynitrite-dependent tryptophan nitration. Chemical Research in Toxicology, 9: 390-396.

28. Denicola A, Souza J M, Gatti RM, Augusto O \& Radi R (1995). Desferrioxamine inhibition of the hydroxyl radical-like reactivity of peroxynitrite: role of the hydroxamic groups. Free Radical in Biology and Medicine, 19: 11-19.

29. Augusto O, Radi R, Gatti RM \& VasquézVivar J (1996). Detection of secondary radicals from peroxynitrite-mediated oxidations by electron spin resonance. Methods in Enzymology, 269: 346-354.

30. Zhu L, Gumm C \& Beckman J S (1992). Bactericidal activity of peroxynitrite. Archives of Biochemistry and Biophysics, 289: 452-457.
31. Reiter RJ, Melchiorri D, Sewerynek E, Poeggeler B, Barlow-Walden L, Chuang J L, Ortiz GG \& Acunacastroviejo D (1995). A review of the evidence supporting melatonin role as an antioxidant. J ournal of Pineal Research, 18: 1-11.

32. Pieri $C$, Marra M, Moroni $F$, Recchioni $R \&$ Marcheselli $F$ (1994). Melatonin: A peroxyl radical scavenger more effective than vitamin E. Life Sciences, 55: 271-276.

33. Barsacchi R, Kusmic C, Damiani E, Carloni P, Greci L \& Donato L (1998). Vitamin E consumption induced by oxidative stress in red blood cells is enhanced by melatonin and reduced by $\mathrm{N}$-acetylserotonin. Free Radical in Biology and Medicine, 24: 1187-1192.

34. Tan DX, Poeggeler B, Reiter RJ , Chen LD, Chen S, Manchester LC \& Barlowwalden LR (1993). The pineal hormone melatonin inhibits DNA-adduct formation induced by the chemical carcinogen safrole in vivo. Cancer Letters, 70: 65-71.

35. Tan DX, Reiter RJ , Chen LD, Poeggeler B, Manchester LC \& Barlowwalden LR (1994). Both physiological and pharmacological levels of melatonin reduce DNA adduct formation induced by the carcinogen safrole. Carcinogenesis, 15: 215-218.

36. Covaci A, Doneanu $C$, Aboul-Enein HY \& Schepens $P$ (1999). Determination of melatonin in pharmaceutical formulations and human plasma by gas chromatographyelectron impact mass spectrometry. Biomedical Chromatography, 13: 431-436.

37. Pozo D, Reiter RJ, Calvo J O \& Guerrero J M (1997). Inhibition of cerebellar nitric oxide synthase and cyclic GMP production by melatonin via complex formation with calmodulin. J ournal of Cell Biology, 65: 430-442.

38. Kondo H, Takahashi M \& Nikin E (1997). Peroxynitrite-induced hemolysis of human erythrocytes and its inhibition by antioxidants. FEBS Letters, 413: 236-238.

39. Rohn TT \& Quinn MT (1998). Inhibition of peroxynitrite-mediated tyrosine nitration by a novel pyrrolopyrimidine antioxidant. European J ournal of Pharmacology, 353: 329-336. 